\title{
Are Firms Constrained By Their Bank? A Pilot Study
}

Manoj Athavale (Athavale @ mnstate.edu), Minnesota State University Moorhead Eugene Bland (Ebland @ fmarion.edu), Francis Marion University

Robert Trimm (Ectrimm @ cotton.vislab.olemiss.edu), University of Mississippi

\begin{abstract}
Financial intermediation theory assigns banks a unique role in the resolution of information asymmetry, while monetary theory assigns banks a unique role in money creation and the transmission of monetary policy. The bank's willingness to lend depends on perceptions of the project's payoffs and the moral rectitude of the borrowers, while the bank's ability to lend depends on the adequacy of the bank's capital and the stance of monetary policy. Small firms are largely dependent on bank financing - information asymmetry, moral hazard and switching costs restrict access to alternate financing sources. If firms were constrained by their bank's ability to lend, measures of bank capital would be significant determinants of the firm's growth. By identifying specific bank-borrower relationships, we explore the hypothesis that a bank's capital adequacy situation has the potential to influence lending decisions and hence affect the bank's asset structure and the small firm's ability to finance operations.
\end{abstract}

\section{Introduction}

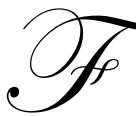

inancial markets require firms to hold capital as a cushion against contingencies and to protect creditors from agency costs of debt. In the context of capital structure theory, a firm will hold that level of capital that will maximize the value of the firm within the unique advantages and constraints it may face. To ensure the safety and soundness of the banking system, bank regulators (The Federal Deposit Insurance Corporation, The Federal Reserve System, and state and federal chartering agencies) impose additional capital requirements that influence the capital structure of banking firms. The introduction of risk adjusted capital requirements together with the banks ability to allocate resources between assets of different risk, has created the potential for influencing the asset structure of banks subject to those capital requirements. Bank loans have long been considered special in the transmission of monetary policy, and the resolution of information asymmetry for small firms. In the absence of reliable and verifiable information about expected project payoff characteristics and the moral rectitude of the borrower, small firms that do not have access to alternate sources of credit may find themselves bound to their bank (the "hold-up" problem). Growth opportunities for the small firm are likely to be constrained by the bank's asset allocation policy. ${ }^{1}$ The actions of the banking sector in allocating between riskier and safer asset classes may also have the unintended consequence of causing a credit crunch and affecting real economic activity.

The theory of financial intermediation is closely associated to the resolution of information asymmetry. Stiglitz and Weiss (1981) showed that information asymmetry might hinder the working of markets, while Leland and Pyle (1977), Campbell and Kracaw (1980) and Diamond (1984) showed that information production could counter market frictions. Fama (1985), James (1987), Lummer and McConnell (1989), James and Wier (1990) and Diamond (1991) showed that bank loans are unique in the resolution of information asymmetry, while Slovin, Johnson and Glascock (1992) emphasized that bank loans are especially unique in the resolution of information asymmetry for small firms. Rajan (1992) and Peterson and Rajan (1994) showed that small firms are especially dependent on their bank for their financing needs.

Readers with comments or questions are encouraged to contact the authors via email.

The banking system is also the focus of the lending view of monetary policy transmission mechanisms (King (1986)). Banks provide unique services (Fama (1985), James (1987), Lummer and McConnell (1989)) by acquiring 
private information over time (Diamond (1991), Rajan (1992), Yamori and Murakami (1999)), which provides the incumbent banks with an information advantage over other creditors. Banks use this information to influence the price and availability of credit (Pertersen and Rajan (1994), Athavale and Edmister (1999)). Banks respond to incentives created by risk based capital requirements (Berger and Udell (1994), Peek and Rosengren (1995), Brinkman and Horvitz (1995), Park (1999)) by reallocating assets to meet capital adequacy requirements and avoid regulatory sanction. Regulatory capital requirements thus have the potential to hinder the capital allocation function and affect real economic activity.

This generally accepted framework of financial intermediation and monetary policy transmission suggests that small firms otherwise qualified for credit, may be constrained by their bank's ability to lend and their bank's asset allocation decisions.

Regulators require banks to meet capital adequacy requirements in order to ensure the safety and soundness of the financial system. Regulatory capital requirements are designed to reduce moral hazard, reduce the agency cost of debt, reduce the risk of bank failure, increase public confidence in the financial system and reduce losses to the Federal Deposit Insurance Corporation. ${ }^{2}$ The regulatory regime attempts to balance between the cost of excessive regulation ("credit crunch") and the cost of too little regulation ("regulatory forbearance"). However, the risk based capital standards implemented by the regulators have the potential for affecting both the capital structure and the asset structure of the bank. The high cost of regulatory sanction (prompt corrective action, mandatory closure, and least cost resolution) incorporated in the provisions of the FDIC Improvement Act, creates the incentives for banks to respond to capital adequacy requirements by changing asset allocations. Since changing capital structure may be costly (Park (1999)), banks can achieve the objective of adjusting their risk-weighted capital by changing the composition of assets in their portfolio.

Extant empirical research (Shrieves and Dahl (1992), Berger and Udell (1994), and Jacques and Nigro (1997)) has evidenced that banks faced with regulatory capital constraints change asset composition by substituting away from high risk-weighted assets. Our research builds on this and other related research (Gertler and Gilchrist (1994), Peek and Rosengren (1995), Brinkman and Horvitz (1995), and Carpenter, Fazzari and Petersen (1998)) by identifying a small firm with its bank, and exploring the hypothesis that the small firm's ability to finance operations may be constrained by its bank's capital adequacy situation. ${ }^{3}$ To the best of our knowledge, this is the first paper to make this direct association.

\section{Data, Methodology And Results}

If the bank's investment decisions were independent of financial and regulatory constraints, we would not expect business firms to be constrained by their bank. However as shown by Shrieves and Dahl (1992), Berger and Udell (1994), and Jacques and Nigro (1997), the existence of regulatory capital constraints may create incentives for banks to substitute away from high risk-weighted assets, thus increase their capital ratios without increasing capital, and avoid market and regulatory sanction. While the influence of the bank on the firm, during periods of "tight" credit has been investigated (Bernanke and Lown (1991), Peek and Rosengren (1995), Berger and Udell (1994), Berger et.al. (1995), Brinkman and Horvitz (1995)), such an influence may persist even during periods of relatively "easy" credit. We therefore chose a recent period of relatively "easy" credit (from the last quarter of 1995 to the last quarter of 1998) to test the hypothesis that the small firm's ability to finance operations may be constrained by its bank's capital adequacy situation. We obtained a preliminary sample of 128 small manufacturing firms (defined as firms with primary SIC code between 2000 and 3999, and average quarterly revenues of less than dollars twentyfive million during the year 1995) from Compact Disclosure. Firm specific quarterly data on sales, total assets and debt-equity ratio was obtained from Compact Disclosure. From the Million Dollar Directory, we obtained the primary bank identified by each firm over the period 1995 to 1998. Bank specific quarterly data on core capital, tier 1 capital and total capital was obtained from the FDIC Call and Thrift Financial Reports. ${ }^{4}$ Firms that had not listed a primary bank (16) or had named a non-depository institution (4) or where complete financial information about the firm and its bank were not available (22) were eliminated from the sample. We also found that some firms had listed different banks in 1995 and 1998. Firms whose primary bank had merged into another bank (47) or had otherwise lost its FDIC certificate ${ }^{5}$ during the period 1995 to 1998 were eliminated from the sample. A small number of firms 
(12) that had reported a change in primary bank between 1995 and 1998 were also eliminated from the sample. To control for economic influences we obtained the quarterly average federal funds rate and gross domestic product from the Federal Reserve Bulletin. Our sample of 351 observations thus consists of the characteristics of 27 firms, their bank and economic variables over the 13 quarters from the fourth quarter of 1995 to the fourth quarter of 1998. Transforming the data from levels to percentage changes resulted in 324 observations. The sample of 324 observations represents our best effort to obtain a usable sample. Our attempts to increase the number of observations by increasing the time period over which observations were selected resulted in a loss of firm-bank cross-sectional observations. The data and the subsequent analysis reflect much of the difficulties associated with obtaining complete, consistent and reliable information on small borrowers and their bank.

If firms were constrained by their bank's ability to lend, measures of bank capital would be significant determinants of the firm's growth. We proxy the dependent variable, the firm's growth opportunities, with two alternate specifications - the variable SALES is the percentage change in net sales, and ASSETS is the percentage change in total assets. In order to determine capital adequacy, bank regulators focus on three alternate specifications of capital - CORE, TIER1 and TOTAL represent the fraction by which the core capital ratio, tier1 capital ratio and total capital ratio respectively exceed the regulatory requirement for those ratios. ${ }^{6}$ Deterioration in capital adequacy is a signal for regulatory scrutiny; hence the bank's ability to finance the firm's growth is hypothesized to depend on the growth in the bank's capital ratios. We therefore calculate dCORE as the percentage change in the core capital ratio, dTIER1 as the percentage change in the tier1 capital ratio, and dTOTAL as the percentage change in the total capital ratio. We control for the firm's financial condition that might affect the lending decision - DEBT is the firm's debt-equity ratio. We also control for general economic conditions - GDP, the percentage change in gross domestic product represents the level of economic activity; and FEDF, the percentage change in the federal funds rate represents the stance of monetary policy.

The model used to test the hypothesis that the firm's growth is linked to the bank's capital situation can generally be stated as -

$$
\text { Firm' sGrowth }=\alpha+\sum_{i=1,3} \beta_{i} \text { ControlVariable }_{i}+\beta_{4} \text { Bank' } \text { Capital }+\beta_{5} \text { GrowthInCapital } \quad \text { Equation } 1
$$

We tested the general model presented above using two alternate specifications of the firm's growth (SALES or ASSETS) and three alternate specifications of the bank's capital situation (CORE and dCORE, or TIER1 and dTIER1, or TOTAL and DTOTAL). The results of the six OLS regression analyses presented in table 1 confirm that the firm's growth opportunities are constrained by their bank's ability to lend.

The intercept and the three control variables (GDP, FEDF and DEBT) were insignificant in all specifications of our model. ${ }^{7}$ We also find that measures of the level of capital adequacy (CORE, TIER1 and TOTAL) were insignificant in all specifications. However, changes in the bank's capital adequacy (dCORE, dTIER1 and dTOTAL) had a positive coefficient and were generally significant determinants of the firm's growth.

\section{Conclusions}

It is well recognized that financial markets are characterized by imperfect information. Banks help financial markets to overcome asymmetric information by screening, contracting with, and monitoring borrowers. Information asymmetry and moral hazard in the transfer of information prevent small firms from seeking alternate sources of financing and are often tied to the incumbent bank. Since 1988, bank regulators have emphasized the importance of risk based capital adequacy requirements; and since 1991, bank regulators have implemented prompt corrective action, mandatory closure, and least cost resolution rules for failure to comply with regulatory requirement. The high cost of regulatory sanction creates incentives for banks to adjust their asset allocation to comply with capital standards, and thus creates a channel by which regulatory policy may influence economic activity. Our results do not find any evidence to suggest that the small firm's growth opportunities are constrained by the level of the bank's capital relative to regulatory norm. Our analysis does confirm that it is the changes in the bank's capital that consistently and significantly influences

\section{Table 1}

The relation between the firm's growth and the bank's capital 
The model used to test the hypothesis that the firm's growth is linked to the bank's capital situation can generally be stated as -

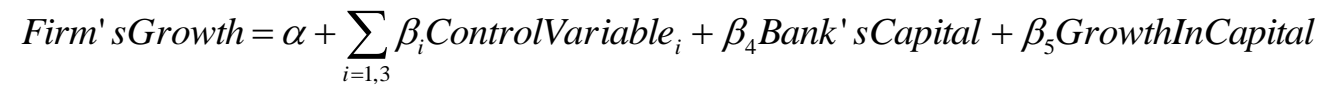

We tested this model using alternate specifications of the firm's growth (SALES or ASSETS) and the bank's capital situation (CORE and dCORE, or TIER1 and dTIER1, or TOTAL and dTOTAL). To the best of our knowledge, this is the first study to identify a firm with its bank and link the firm's growth opportunities to the bank's capital situation. The results of the six OLS regression analyses confirm that the firm's growth opportunities are constrained by the their bank's ability to lend. The results suggest that it is the changes in the bank's capital that influence the firm's growth opportunities, and it is the growth of the firm's assets that is primarily influenced.

\begin{tabular}{|c|c|c|c|c|c|c|}
\hline \multirow{3}{*}{$\begin{array}{l}\text { Variable } \\
\text { Dependent Variable } \\
\text { Measure of Bank Capital }\end{array}$} & \multicolumn{6}{|c|}{ Coefficients } \\
\hline & \multicolumn{3}{|c|}{ SALES } & \multicolumn{3}{|c|}{ ASSETS } \\
\hline & Core & Tier1 & Total & Core & Tier1 & Total \\
\hline Intercept & $\begin{array}{l}0.03 \\
(0.29)\end{array}$ & $\begin{array}{l}0.01 \\
(0.09)\end{array}$ & $\begin{array}{l}-0.00 \\
(-0.02)\end{array}$ & $\begin{array}{l}-0.01 \\
(-0.56)\end{array}$ & $\begin{array}{l}-0.02 \\
(-0.71)\end{array}$ & $\begin{array}{l}-0.02 \\
(-1.07)\end{array}$ \\
\hline GDP & 3.87 & 4.35 & 3.77 & 1.66 & 2.01 & 1.88 \\
\hline Percentage change in gross domestic output & $(0.66)$ & $(0.75)$ & $(0.65)$ & $(1.13)$ & $(1.36)$ & $(1.27)$ \\
\hline FEDF & 0.08 & 0.10 & 0.10 & 0.13 & 0.15 & 0.15 \\
\hline Percentage change in federal funds rate & $(0.18)$ & $(0.21)$ & $(0.21)$ & $(1.09)$ & $(1.22)$ & $(1.24)$ \\
\hline DEBT & -0.00 & -0.00 & -0.00 & -0.00 & -0.00 & -0.00 \\
\hline Firm's debt-equity ratio & $(-0.87)$ & $(-0.81)$ & $(-0.89)$ & $(-1.08)$ & $(-0.97)$ & $(-1.05)$ \\
\hline CORE & -0.03 & & & -0.00 & & \\
\hline $\begin{array}{l}\text { Fraction by which the core capital ratio exceeds the } \\
\text { regulatory requirement }\end{array}$ & $(-0.68)$ & & & $(-0.16)$ & & \\
\hline dCORE & 0.25 & & & $0.12 *$ & & \\
\hline Percentage change in the core capital ratio & $(1.62)$ & & & $(3.19)$ & & \\
\hline TIER1 & & -0.02 & & & -0.00 & \\
\hline $\begin{array}{l}\text { The fraction by which the tierl capital ratio exceeds } \\
\text { the regulatory requirement }\end{array}$ & & $(-0.60)$ & & & $(-0.39)$ & \\
\hline dTIER1 & & 0.26 & & & $0.09 *$ & \\
\hline Percentage change in the tier 1 capital ratio & & $(1.65)$ & & & $(2.31)$ & \\
\hline TOTAL & & & -0.02 & & & 0.01 \\
\hline $\begin{array}{l}\text { The fraction by which the total capital ratio exceeds } \\
\text { the regulatory requirement }\end{array}$ & & & $(-0.19)$ & & & $(0.52)$ \\
\hline dTOTAL & & & $0.40^{*}$ & & & $0.10 *$ \\
\hline Percentage change in the total capital ratio & & & $(2.13)$ & & & $(2.18)$ \\
\hline DW & 2.30 & 2.30 & 2.30 & 1.90 & 1.91 & 1.92 \\
\hline
\end{tabular}

Note: * denotes that the coefficient is significant at $5 \%$. The t-statistic is placed below the coefficient in parenthesis $(n=324)$. The variables used in our analysis was suggested by accepted theory and prior studies which had used macro level data instead of the firm level data employed in this study. Since we were interested in analyzing the firm's growth opportunities and constraints to those opportunities, we transformed variables from levels to percentage changes, which confounds interpretation of measures of fit.

growth of the firm's assets. The evidence does suggest that banks are sensitive to changes in their capital adequacy and adjust their lending decisions in response to such changes. Deterioration in a bank's capital adequacy may therefore result in an allocation of credit to the detriment of small businesses. This pilot study raises implications for the manner in which firms form relationships with banks - small firms may be better served by diversifying financing sources and forming multiple banking relationships to ensure availability of credit to finance asset growth.

\section{Suggestions for Future Research}


Our knowledge of "relationship intermediation", the manner in which banks and the borrowing firms interact has been developing. This interaction is important because it impacts the terms and availability of credit to businesses and can influence the firm's growth opportunities. At this time, the lack of a clear consensus in the theoretic and empirical literature and the need for resolution creates a promising avenue for further research.

\section{Endnotes}

1. A bank may be able to meet risk adjusted capital adequacy requirements and avoid regulatory sanction by (for example) decreasing the proportion of business loans which have higher risk weights and increasing the proportion of U.S. government securities which have lower risk weights.

2. Examples of regulatory influences on capital standards include the International Lending and Supervision Act of 1983, Basle Agreement on International Capital Standards of 1987, and the Federal Deposit Insurance Corporation Improvement Act of 1991.

3. Slovin, Sushka and Polonchek (1993) find negative excess stock returns to firms with business dealings with Continental Illinois Bank around the time of the banks failure, and positive excess stock returns to those firms when the bailout package was announced, supporting the proposition that banking conditions affect borrowers. Yamori and Murakami (1999) also find that information sensitive relationships are difficult to replicate and adversely affect bank customers. Bernanke and Lown (1991) and Hancock and Wilcox (1998) discuss the proposition that changes in bank lending affect the aggregate economy.

4. The core capital ratio is defined as tier1 capital as a percentage of assets. The tier1 capital ratio is defined as tier1 capital as a percentage of risk-weighted assets. The total capital ratio is defined as total capital as a percentage of risk-weighted assets. Details of capital composition are available in Regulation Y (12 CFR 225 App. A).

5. A unique number assigned by the FDIC, which is used to identify institutions, and for the issuance of insurance certificates.

6. Regulators currently require banks to hold three-percent core capital, four-percent tier 1 capital, and eightpercent total capital.

7. Since many of the small firms in our sample are likely to be influenced by "regional" characteristics, we matched the firm to its region as specified by the Bureau of Economic Analysis, U.S. Department of Commerce. We then replaced the GDP variable with the corresponding regional personal income. The interpretation of the regression analysis was qualitatively similar to the original analysis and confirmed the robustness of our results.

\section{References}

1. Athavale, Manoj and Robert O. Edmister, "Borrowing relationships, monitoring and the influence on loan rates," The Journal of Financial Research Vol. 22, pp. 341-352, 1999.

2. Berger, Allen N. and Gregory F. Udell, "Did risk-based capital allocate bank credit and cause a "credit crunch' in the United States?" Journal of Money, Credit and Banking Vol. 26, pp. 585-628, 1994.

3. Berger, Allen N., Richard J. Herring, and Giorgio P. Szego, "The role of capital in financial institutions," Journal of Banking and Finance Vol. 19, pp. 393-430, 1995.

4. Bernanke, Ben S. and Cara S. Lown, "The credit crunch," Brookings Papers on Economic Activity Vol. 2, pp. 205-239, 1991.

5. Brinkman, Emile J. and Paul M. Horvitz, "Risk-based capital standards and the credit crunch," Journal of Money, Credit and Banking, pp. 848-863, 1995.

6. Campbell T., and W. Kracaw, "Information production, market signaling and the theory of intermediation," Journal of Finance Vol. 35, pp. 863-882, 1980.

7. Carpenter, Robert E., Steven M. Fazzari and Bruce C. Petersen, "Financing constraints and inventory investment: A comparative study with high-frequency panel data," The Review of Economics and Statistics Vol. 80, pp. 513-519, 1998.

8. Degryse, Hans and Steven Ongena, "Bank relationships and Firm Profitability," Financial Management Vol. 30, pp. 9-34, 2001.

9. Diamond, Douglas W., "Financial intermediation and delegated monitoring," Review of Economic Studies 
Vol. 51, pp. 393-414, 1984.

10. Diamond, Douglas W., "Monitoring and reputation: The choice between bank loans and directly placed debt," The Journal of Political Economy Vol. 99, pp. 689-721, 1991.

11. Fama, Eugene, "What's special about banks?" The Journal of Monetary Economics Vol. 15, pp. 29-39, 1985.

12. Gertler, Mark and Simon Gilchrist, "Monetary policy, business cycles, and the behavior of small manufacturing firms," The Quarterly Journal of Economics Vol. 109, pp. 309-340, 1994.

13. Hancock, Diana and James A. Wilcox, "The "credit crunch" and the availability of credit to small business," Journal of Banking and Finance Vol. 22, pp. 983-1014, 1998.

14. Jacques, Kevin and Peter Nigro, "Risk based capital, portfolio risk and bank capital: A simultaneous equations approach," Journal of Economics and Business Vol. 49, pp. 533-547, 1997.

15. James, Christopher, "Some evidence on the uniqueness of bank loans," Journal of Financial Economics Vol. 19, pp. 217-236, 1987.

16. James, Christopher and Peggy Wier, "Borrowing relationships, intermediation, and the cost of issuing public securities," Journal of Financial Economics Vol. 28, pp. 149-171, 1990.

17. King, Stephen, "Monetary transmission: Through bank loans or bank Liabilities," Journal of Money, Credit and Banking, pp. 290-303, 1986.

18. Leland, H. and D. Pyle, "Information asymmetries, financial structure, and financial intermediaries," Journal of Finance Vol. 32, pp. 371-387, 1977.

19. Lummer, Scott and John McConnell, "Further evidence on the bank lending process and the capital-market response to bank loan agreements," Journal of Financial Economics Vol. 25, pp. 99-122, 1989.

20. Park, Sangkyun, "Effects of risk-based capital requirements and asymmetric information on banks' portfolio decisions," Journal of Regulatory Economics Vol. 16, pp. 135-150, 1999.

21. Peek, Joe and Eric Rosengren, "The capital crunch: Neither a borrower nor a lender be," Journal of Money, Credit and Banking, pp. 625-638, 1995.

22. Petersen, Mitchell A. and Raghuram G. Rajan, "The benefits of lending relationships: Evidence from small business data," The Journal of Finance Vol. 49, pp. 407-443, 1994.

23. Rajan, R., "Insiders and outsiders: The choice between informed and arms length debt," Journal of Finance Vol. 47, pp. 1367-1400, 1992.

24. Shrieves, R. and D. Dahl, "The relationship between risk and capital in commercial banks," Journal of Banking and Finance Vol. 16, pp. 439-457, 1992.

25. Slovin, Myron B., Shane A. Johnson and J. L. Glascock, "Firm size and the information content of bank loan announcements," Journal of Banking and Finance Vol. 16, pp. 1057-1072, 1992.

26. Slovin, Myron B., Marie E. Sushka and J. Polonchek, "The value of bank durability: Borrowers as bank stakeholders,” Journal of Finance Vol. 48, pp. 247-266, 1993.

27. Stiglitz, Joseph, and Andrew Weiss, "Credit rationing in markets with imperfect information," American Economic Review Vol. 71, pp. 393-410, 1981.

28. Yamori, Nobuyoshi and Akinobu Murakami, "Does bank relationship have an economic value?" Economics Letters Vol. 65, pp. 115-120, 1999. 


\section{Do Not print this page and beyond!!!!}

Notes

1. A bank may be able to meet risk adjusted capital adequacy requirements and avoid regulatory sanction by (for example) decreasing the proportion of business loans which have higher risk weights and increasing the proportion of U.S. government securities which have lower risk weights.

2. Examples of regulatory influences on capital standards include the International Lending and Supervision Act of 1983, Basle Agreement on International Capital Standards of 1987, and the Federal Deposit Insurance Corporation Improvement Act of 1991.

3. Slovin, Sushka and Polonchek (1993) find negative excess stock returns to firms with business dealings with Continental Illinois Bank around the time of the banks failure, and positive excess stock returns to those firms when the bailout package was announced, supporting the proposition that banking conditions affect borrowers. Yamori and Murakami (1999) also find that information sensitive relationships are difficult to replicate and adversely affect bank customers. Bernanke and Lown (1991) and Hancock and Wilcox (1998) discuss the proposition that changes in bank lending affect the aggregate economy.

4. The core capital ratio is defined as tier1 capital as a percentage of assets. The tier1 capital ratio is defined as tier1 capital as a percentage of risk-weighted assets. The total capital ratio is defined as total capital as a percentage of risk-weighted assets. Details of capital composition are available in Regulation Y (12 CFR 225 App. A).

5. A unique number assigned by the FDIC, which is used to identify institutions, and for the issuance of insurance certificates.

6. Regulators currently require banks to hold three-percent core capital, four-percent tier 1 capital, and eight-percent total capital.

7. Since many of the small firms in our sample are likely to be influenced by "regional" characteristics, we matched the firm to its region as specified by the Bureau of Economic Analysis, U.S. Department of Commerce. We then replaced the GDP variable with the corresponding regional personal income. The interpretation of the regression analysis was qualitatively similar to the original analysis and confirmed the robustness of our results. 
Table 1

The relation between the firm's growth and the bank's capital

The model used to test the hypothesis that the firm's growth is linked to the bank's capital situation can generally be stated as -

$$
\text { Firm' sGrowth }=\alpha+\sum_{i=1,3} \beta_{i} \text { ControlVariable }_{i}+\beta_{4} \text { Bank' }^{\prime} \text { Capital }+\beta_{5} \text { GrowthInCapital }
$$

We tested this model using alternate specifications of the firm's growth (SALES or ASSETS) and the bank's capital situation (CORE and dCORE, or TIER1 and dTIER1, or TOTAL and dTOTAL). To the best of our knowledge, this is the first study to identify a firm with its bank and link the firm's growth opportunities to the bank's capital situation. The results of the six OLS regression analyses confirm that the firm's growth opportunities are constrained by the their bank's ability to lend. The results suggest that it is the changes in the bank's capital that influence the firm's growth opportunities, and it is the growth of the firm's assets that is primarily influenced.

\begin{tabular}{|c|c|c|c|c|c|c|}
\hline \multirow{3}{*}{$\begin{array}{l}\text { Variable } \\
\text { Dependent Variable } \\
\text { Measure of Bank Capital }\end{array}$} & \multicolumn{6}{|c|}{ Coefficients } \\
\hline & \multicolumn{3}{|c|}{ SALES } & \multicolumn{3}{|c|}{ ASSETS } \\
\hline & Core & Tier1 & Total & Core & Tier1 & Total \\
\hline Intercept & $\begin{array}{l}0.03 \\
(0.29)\end{array}$ & $\begin{array}{l}0.01 \\
(0.09)\end{array}$ & $\begin{array}{l}-0.00 \\
(-0.02)\end{array}$ & $\begin{array}{l}-0.01 \\
(-0.56)\end{array}$ & $\begin{array}{l}-0.02 \\
(-0.71)\end{array}$ & $\begin{array}{l}-0.02 \\
(-1.07)\end{array}$ \\
\hline GDP & 3.87 & 4.35 & 3.77 & 1.66 & 2.01 & 1.88 \\
\hline Percentage change in gross domestic output & $(0.66)$ & $(0.75)$ & $(0.65)$ & $(1.13)$ & $(1.36)$ & $(1.27)$ \\
\hline FEDF & 0.08 & 0.10 & 0.10 & 0.13 & 0.15 & 0.15 \\
\hline Percentage change in federal funds rate & $(0.18)$ & $(0.21)$ & $(0.21)$ & $(1.09)$ & $(1.22)$ & $(1.24)$ \\
\hline DEBT & -0.00 & -0.00 & -0.00 & -0.00 & -0.00 & -0.00 \\
\hline Firm's debt-equity ratio & $(-0.87)$ & $(-0.81)$ & $(-0.89)$ & $(-1.08)$ & $(-0.97)$ & $(-1.05)$ \\
\hline CORE & -0.03 & & & -0.00 & & \\
\hline $\begin{array}{l}\text { Fraction by which the core capital ratio exceeds the } \\
\text { regulatory requirement }\end{array}$ & $(-0.68)$ & & & $(-0.16)$ & & \\
\hline dCORE & 0.25 & & & $0.12 *$ & & \\
\hline Percentage change in the core capital ratio & $(1.62)$ & & & (3.19) & & \\
\hline TIER1 & & -0.02 & & & -0.00 & \\
\hline $\begin{array}{l}\text { The fraction by which the tier } 1 \text { capital ratio exceeds } \\
\text { the regulatory requirement }\end{array}$ & & $(-0.60)$ & & & $(-0.39)$ & \\
\hline dTIER1 & & 0.26 & & & $0.09^{*}$ & \\
\hline Percentage change in the tier1 capital ratio & & $(1.65)$ & & & $(2.31)$ & \\
\hline TOTAL & & & -0.02 & & & 0.01 \\
\hline $\begin{array}{l}\text { The fraction by which the total capital ratio exceeds } \\
\text { the regulatory requirement }\end{array}$ & & & $(-0.19)$ & & & $(0.52)$ \\
\hline dTOTAL & & & $0.40 *$ & & & $0.10^{*}$ \\
\hline Percentage change in the total capital ratio & & & (2.13) & & & $(2.18)$ \\
\hline DW & 2.30 & 2.30 & 2.30 & 1.90 & 1.91 & 1.92 \\
\hline
\end{tabular}

Note: $*$ denotes that the coefficient is significant at $5 \%$. The t-statistic is placed below the coefficient in parenthesis $(\mathrm{n}=324)$. The variables used in our analysis was suggested by accepted theory and prior studies which had used macro level data instead of the firm level data employed in this study. Since we were interested in analyzing the firm's growth opportunities and constraints to those opportunities, we transformed variables from levels to percentage changes, which confounds interpretation of measures of fit. 